\title{
The Meanings of the Dative Case of Nouns in Impersonal Sentences in the Russian Language
}

\author{
Nia Kurnia Sofiah ${ }^{1}$ \\ niadee@gmail.com ${ }^{1}$ \\ Universitas Indonesia, Indonesia ${ }^{1}$
}

\begin{abstract}
The dative case for nouns in general is to indicate the recipient or beneficiary of an action. In some points, this general meaning is also applied in Russian language. However, the dative case in the Russian language has special meanings. There are nine meanings for the dative case of nouns in the Russian language. This paper discusses the usage of the dative case in impersonal sentences in the Russian Language. The meanings are connected to the Russian identities and will affect the translations of the Russian texts using the dative case of nouns. The morphosyntax will be used to analyze the sentences using the nouns with the dative case. In the results, the Russian culture will be revealed. The source for this paper is Смерть Ивана Ильича (Smert' Ivana Il'icha) "The Death of Ivan Ilyich" written by Lev Tolstoy printed in 2014.
\end{abstract}

Keywords: Linguistics, Dative, Nouns, Russian Language, Translation

\section{Introduction}

The Russian language is a language with cases for nouns. This language has six cases for nouns which is Именительный падеж (Imenitel'nyj padez) 'Nominative case', Родительный падеж (Roditel'nyj padez) 'Genetive case', Дательный падеж (Datel'nyj padez) 'Dative case', Винительный падеж (Vinitel'nyj padez) 'Akusative case', Творительный падеж (Tvoritel'nyj padez) 'Instrumental case' and Предложный падеж (Predloznyj padez) 'Prepositional case' [1]. These each cases have their own functions in revealing the expressions in the Russian language. This paper will discuss the Dative case.

In understanding texts in Russian language, we need to make sure that we can understand the sentences and their messages. In order to understanding the messages, the translations are needed. There are methods and procedures that can be applied. There will things that we need to consider in applying the methods and procedures in understanding the Dative case of Russian sentences in the literature products such as the novel we use here as the source of the data for this paper.

\section{Literature review}

\section{1 The Dative case}

The general meaning for dative case in Russian language is indirect object for answering the questions кому? (komu?) 'to whom?' and чему? (cemu?) 'to what?'[2]. There are nine meanings for the Dative case [3]. First, the recipient. Second, verb "to like". Third, age. Fourth, in impersonal sentences: the person (object) experiencing a certain state or condition. Fifth, the 
person who is the aim of the motion. Sixth, an object or a place to which motion is directed. Seventh, motion along the surface. Eighth, the attribute formed from the subjects of education. Ninth, way (means) of communication. This paper will focus on the fourth meaning of the Dative case.

\subsection{The impersonal sentences}

The fourth meaning of the dative case is in impersonal sentences: the person (object) experiencing a certain state or condition. The words such as надо (nado) 'need' and нужно (nuzno) 'have to', the adverbs, and the dative cases of nouns and pronouns will be applied in sentences. Мне надо пить (mne nado pit'). Мне (mne) is the dative case for I. The literal meaning is the activity of drink is needed to me or I am in the situation of thirst. I can be translated as I need to drink or I am thirsty. Антону нужно много заниматься (Antonu nuzno mnogo zanimat'sja). Антону (Antonu) is the dative case of Anton. The literal meaning is to Anton the learning hard is a duty. The adapted translation will be Anton has to learn hard. These show that there is a change of the function of I and Anton. In the literal meaning, I is functioning as the object while in the adapted translation, I and Anton become the subject. The translation methods are needed to make sure that we can translate the impersonal sentences well in order to understand the messages of the sentences.

\subsection{The Translation methods and procedures [4]}

The translation methods. The translation method is the way a texts is translated. There are eight methods for translations. First, it is word for word translation method. This method is a method that align directly word for word the source language with the target language. The sentence structure will use the source language structure and the meaning of each word will be translated without taking the contexts into account. This can be used as the initial process of the translation. This method is only suitable for texts or sentences with no cultural base or implied meanings. Second, it is the Literal translation method. The sentence structure will be based on the target language but the words or expressions might be translated out of context since the words with cultural based meaning will be translated literally. This leads to a situation that the implied meanings or the messages can be transferred in the target language. This method can be applied as the outcome of the translation process. Third, it is the Faithful translation method. The contextual meaning can be achieved from this method since the contexts are taken into account. However, the sentence structure, the paragraphs and texts in general are still limited by the grammatical structure of the source language although it is true that the structure of the target language follows the source language. The results will be rigid and strange since they are restricted by the pattern and the structure of the source language for the sentences and the texts. Fourth, it is the Semantic Translation method. This method is considered as more flexible than the faithful method. The structures have followed the target language and contexts has taken into account for the meanings and the messages but the expressions with the cultural contents are still translated neutral or no emotional based or just functional. The academic text will be suitable for this method since there is no ambiguity for the texts and the results of the translation. Fifth, it is the Communicative translation method. This method will be more flexible for the texts with cultural contents than the semantic method since this method will reveal the messages from the source language by applying all the conversions of the target language. This will make it more communicative since it will make it easier for the target readers to understand the messages. This method is suitable for brochures, announcements, popular writing and alike. 
Sixth, it is the Idiomatic translation method. This method is trying to translate the idiomatic expressions in the source language also as the idiomatic expression in the target language. This can make the readers fell closer to the texts but the scope of this method is narrow since the focus is only on the idiomatic expressions. The suitable texts are poetry, drama, novel and alike. Seventh, it is the Free translation method. This method is focusing on the important parts of the messages for the readers not the whole messages. This method gives the contents but sacrifices the forms of the source language. The paraphrasing is applied in this method that can make the translation results shorter or longer than it is written in the source language. The suitable texts for this method are journalistic texts and alike. Eight, it is the Adaption translation method. This method is considered as the farthest and the freest translation from the source language. The texts of drama, poetry, film transcripts and alike are translated using this method by maintaining the theme, characters and plot while the sentences, the dialogs and the expressions in them has been changed based on the culture and language of the target viewers. One of the examples is the Mahabharata. This story has different versions for the Indian version and the Javanese version.

The translation procedures. There are six procedures of translations. First is the Transpositional translation procedure. The transpositional is shifting structurally from the source language to the target language. Thera are two shifts: the Level shift and the Category shift. Second is the Modulation. This procedure can also be taken as the procedure of the semantic shift. There are two kinds of the modulation: the modulation of viewpoint and the modulation of meaning scope. Third is there are five procedures in this group which are the Contextual conditioning, the Cultural Equivalent, the Descriptive terms, the Functional terms, the Couplets and Triplets. Most of the procedures in this group focus on providing additional explanations to a product, an object or a term while one procedure which is the cultural equivalent focuses on searching the suitable equivalent connected to the culture in the target language. These all procedures are often applied simultaneously and these procedures are about the messages rather than the meanings and the forms. Fourth is The metaphors and the idioms. There are three procedures for metaphors and idioms: translate faithfully if it is universal, find the equivalent if the metaphors and idioms are culturally based, and translate or decipher the messages from the source language to the target language if there is no equivalent. Fifth is Explicitation, Implicitation, Deletion and Addition. The aim of all of the procedures in this group is to make sure that the translation will be effective and efficient. Sixth is Calque, Naturalization, and Transference. The sixth procedures do not need contexts or even texts since these procedures are applied only for word and phrase levels.

\section{Method}

This research is a descriptive research aiming at describing how the impersonal sentences in the Russian language connected to the identities of the Russian people. The data is from the novel titled Смерть Ивана Ильича (Smert' Ivana Il'icha) “The Death of Ivan Ilyich" written by Lev Tolstoy printed in 2014 [5]. The data consist of sentences in the Dative case for the nouns in the impersonal sentences. The morphosyntax and the translations methods and procedures will be applied for analyzing the sentences. 


\section{Result and discussion}

\subsection{The Result}

The source of the data is a novel. Based on the findings, the methods and the procedures to discuss the data are not use pure a specific method or procedure only but combinations of methods and procedures. It happens since there are cultural based sentences or expressions from the data. Therefore, we need to be careful in translating the texts or sentences in order to find the real messages and meanings. Based on the discussions, it can be revealed that the Russian identities strongly connected to the Russian culture are shown in the data. The strongest findings about the identity is the way the Russian people express their feelings or situations by using the impersonal sentences meaning that in the Russian community, it is not the individual doers as the focus or the subjects of the sentences but the feelings or the situations shown as the adverbs. The doer is not the subject but as the indirect object in the sentences. Actually, there is no subject at all in the sentences, only adverbs and the modals (such as надо (nado) 'need', нужно (nuzno) 'have to', нельзя (nel'zja) 'forbidden' as the predicate of the sentences.

\subsection{The Discussion}

Based on the data findings, we are going to show you the result and discussion. The discussions will be based on the sentences with the dative case of the impersonal sentences and analysis with the morphosyntax and the translation methods and procedures. The data will not be written as the whole or a complete sentence but only on the impersonal parts. There are ten data discussed as follows:

The first data is: ..., кому и какую помощьь нужно было оказывать (... komu i kakuju pomosh nuzno bylo okazyvat'). The literal meaning for this sentence is to whom and what kind of help have to provide. If we take the literal meaning, we are going to feel confused about the meaning and the message. The literal meaning is useful as the initial process of the translation. As for the morphosyntax, there is a dative case there which is shown by the word komy (komu) as the recipient and we can translate it into 'to whom'. In this sentence, there is no subject written, only the predicate which is нужно было оказывать (nuzno bylo okazyvat') 'have to be provided'. Какую помощь (kakuju pomosh) syntactically is the direct object since it is written in accusative case. Therefore, we need to rearrange the translation in order to make it more communicative and more understandable. This becomes: ..., what kind of help is needed to provide and for whom. The last translation is better since in English the existence of subject is vital. If there is no subject, it will be hard to understand the sentence. We rearrange the structure and put the word 'what kind of help' as the subject. It is contrast to Russian language. In Russian language that are expressed by the Russian people, the sentence does not always need subject since the focus is not the subject. It is the recipient that is taken into account. It means that no matter who will provide the help, the help must be provided to the recipient. In the first sentence since it is part of a complete sentence indicating of not knowing yet the recipient, therefore the word komy (komu) 'to whom' is used.

The second data is: - Тебе, стало быть, нужно лесу, а не сошек; так и говорить надо было. (-tebe, stalo byt', nuzno lesu, a ne soshek; tak i govorit' nado bylo). The literal meaning for this sentence is 'to you, need to forest, not a bough, like that and talk is needed'. The word стало быть (stalo byt') is written to indicate that there is no subject written in the sentence. The word тебе (tebe) is the dative case for the second single pronoun as the recipient. However, in translating the sentence, we need to rearrange the literal meaning and take the context into 
account. The context is that the person who needs land to provide himself a house or a castle as a rich and noble man. The Russian people take the forest as a land or a place where we can build a house on it. We can translate the sentence into: 'Therefore, you had to say that you need a forest, not a bough'. We change the position of you, not as the indirect object anymore but as the subject. It is very unique since in Russian culture, the wealth, the age and the nature (and the forest is part of it) is given (by God). Therefore, it is the dative case playing a big role for expressing the situation.

The third data: Нехлюдову было посадно и больно ... (Nexljudovu bylo posadno i bol'no ...). The literal meaning is 'to Nexlyudov is plant and hurt'. It will be confusing to take the literal meaning. Actually, the real meaning of it is 'Nexljudov was in trouble and hurt'. In Russian culture, in order to express feelings and situation, they never use the pronouns in the nominative case as the subject since the situations or the feelings is the focus. Furthermore, the feelings are also given (by God). Therefore, if you feel something, you will put yourself as the recipient of the feelings in your expressions in Russians. It is very different from expression of feeling in English. The person who is in the situations or the feelings will be written in nominative case. That is the reason why we need to recompose the translation of a Russian sentence with the dative case where the feeling expressions are also applied if we want to make sure that the English speakers understand the message or the meaning.

The fourth data: В этой избе тебе жить нельзя; ...(V etoj izbe tebe zit' nel'zja). The literal meaning for this sentence is 'in this hut to you live forbidden'. It is truly a disastrous translation if we take it as a final one since it does not make any sense. The word нельзя (nel'zja) 'forbidden' demands the pronouns written in dative case since it is given the order not to do something. If we want to translate it into English, we need to use the English structure to make sure that the English speakers can understand it. It is rearranged into "You cannot live in this hut'. This will be softer and more emotionally than saying 'It is forbidden for you to live in this hut'. We can take those two alternatives for the final translation.

The fifth data: - и ему стало что-то тяжело, грустно и чего-то совестно. (-і ети stalo cto-to tjazelo, grustno i cego-to sovestno.). The literal meaning is 'and to him something hard, sad and something ashamed'. This sentence has feelings expressions in it, therefore the dative case, specifically impersonal sentence takes a role here. There is no subject in the sentence. That is the reason why the predicate is written in neutral form - стало (stalo) since it is not expressed in the sentence. The Russian culture take the feelings as given therefore the one who has the feelings is the recipient and written as the dative in impersonal sentence. This applies for this fifth sentence. The word emy (emu) is the dative case for the third single pronoun with masculine gender. So, we can recompose the translation into: 'and he felt something hard, sad and somehow ashamed'

The sixth data: ...; как будто ему смешно было, что барин делает такие глупье бonpocbl. (...; kak budto emu smeshno bylo, cto barin delaet takie glupye v oprosy.). The literal meaning of this sentence is 'as if to him funny, that the master makes such stupid questions'. The second part is easy to understand. However, the first part is not clear. The word было (bylo) indicates that there is no subject in the first part therefore it is the neutral form is written in the sentence. Funny is a situation and the Russian language expresses the situation in the dative case with the impersonal sentence. As mentioned before that the word emy (emu) is the dative case for the third single pronoun with masculine gender. So, the translation into English can be modified to 'as if it was funny to him that the master makes such stupid questions'.

The seventh data: - и мне бы легче было, да и им-то лучше, чем здесь горе мыкать... (-i mne by legce bylo, da i im-to lucshe, cem zdes' gore mykat'...). The literal meaning is 'and to me easier, yes to them better, than here grieve'. The literal meaning cannot be taken as the 
final translation since it is hard to understand the meaning. We need to recompose it according to the target language, in this case, to English. As mentioned above that the neutral form for the verb acting as the predicate indicating that the subject does not exist in the sentence or implied. This is shown in the word было (bylo). Therefore, we need to give subject in the English meaning to make sure that the meaning in English will be understandable. The sentence also states a situation with the words легче (legce) 'easier' and лучше (lucshe) 'better'. This makes the sentence showing an impersonal sentence for someone in a certain situation. The English translation can be written as 'and it would be easier for me, and it is better for them than to grieve here'.

The eight data: Молодому барину стало неловко, ... (Molodomu barinu stalo nelovko, ...). The literal meaning is 'to the young master became embarrassed'. The word стало (stalo) as mentioned before is the predicate written in the neutral form to indicate that there is no subject in the sentence. It is impersonal sentence showing a person in certain situation. The word неловко (nelovko) 'embarrassed' is stating a situation or a feeling. Therefore, in Russian language, it is the dative case is used for the persons who feels it. Молодому барину (Molodomu barinu) is the dative case for молодой барин (molodoj barin) 'young master'. The final translation can be 'The young master became embarrassed'. We write the young master as the subject in the English sentence, not as indirect object as in the Russian one.

The ninth data: - Зачем же тебе нужны деньги? (-Zacem ze tebe nuzny den'gi?). The literal meaning in 'What for to you money is needed'. This translation sounds awkward in English while in Russian language, it is common to use dative case when the word нужно (nuzno) is applied in the sentence. Нужны (nuzny) is a variation of нужно (nuzno) as a predicate for the plural subject. Деньги (den'gi) is a plural. It is common in the Russian language to write money in its plural form. So, the subject of the Russian sentence is the money. However, in translating the sentence into English, we need to change it based on the English structure. The final translation can be 'Why do you need money?'

The tenth data: ..., вам это все известно, ...(..., vam eto vse izvestno, ...). The literal meaning of this sentence is '..., to you it all known'. The word известно (izvestno) is an adverb indicating a situation therefore the pronoun is written as dative. The word вам (vam) is the dative form of the second plural pronoun - вы (vy) 'you'. Вы (vy) 'you' can also be taken as an address form for politeness if the person is singular. This sentence is impersonal and showing a person in a certain situation. The English version for the sentence can be '..., You know all of this, ...'

\section{Conclusion}

This paper points out that the dative case in Russian language have impersonal sentences showing people or objects in certain state (and feelings are included). The signals for these are the modals such as нужно (nuzno), надо (nado) and нельзя (nel'zja); and adverbs. Those words will push the nouns including the pronouns written in dative. It is also common to have a sentence in Russian without any subjects or the subjects are implied. If there are no subjects clearly stated in the sentence, the predicates will be written in the neutral forms.

In order to understand the sentences or the expressions, we need to translate them based on the target language. If English is the target language, we need to make sure that there is a subject in the sentence. Therefore, we need to modify the translation according to the English patterns. 
The data also shows the Russian identity. For Russians, situations and feelings is given. Therefore, the one who is in the situation or has the feelings is the recipient not the doers. This is shown by the usage of the dative case in the sentences above. That is also the reason why there is no nominative case for pronouns or names in impersonal sentence.

\section{References}

[1] Adamcik Nikolaj Vladimirovic., Samyj Polnyj Kurs Russkogo Jazyka. Minsk: Belorusskij Dom Pecati, 2008.

[2] S, A. Kuznetsov., Bol'shoj Tolkovyj Slovar' Russkogo Jazyka. Sankt - Peterburg: Norint, 2000.

[3]. N. V. Kuz'mina., Russian Grammar in Tables. Moskva: Flinta, 2017.

[4]. Haru Deliana Dewi and Andika Wijaya. Dasar-Dasar Penerjemahan Umum. Bandung: Manggu Makmur Tanjung Lestari, 2020.

[5]. L. Tolstoj., Smert' Ivana Il'ica. Sankt - Peterburg: Azbuka, 2014 